Pugachevska K.S., $\mathrm{PhD}$ in Economics

Kyiv National University of Trade and Economics, Kyiv, Ukraine

ORCID: 0000-0002-0473-3119 https://publons.com/researcher/2227037/kateryna-pugachevska/

Pugachevska K.Y., $\mathrm{PhD}$ in Economics, Associate Professor, Mukachevo State University, Mukachevo, Ukraine ORCID: 0000-0002-0921-6583

https://publons.com/researcher/3104617/kateryna-pugachevska/

\title{
DETERMINANTS OF OPEN ECONOMIES EXPORT ORIENTATION
}

This paper primarily aims to explore the determinants of export orientation in terms of neo-protectionism of the 21st century and to identificate the level of Ukraine's export orientation on the basis of combinatorial approach which included the calculation of export openness indicators and export commodity structure. The article deals withthe leading trends of foreign trade liberalization. The present study analyzes scientific views of leading economic schools on the relationship of foreign trade policy and economic growth. The empirical findings indicate the expansion of application of regulatory measures both by the governments and international institutions; coordinating and promoting international cooperation in the areas of multilateral liberalization of foreign trade; increasing the use of non-tariff regulation measures to protect the domestic market from foreign competition. The results provided empirical support of ways of strengthening of export potential in Ukraine based on determinants of export orientation in modern conditions.

Key words: export orientation, export promotion, open economy, free trade policy, international competitiveness.

Пугачевська Катерина Сергї̈вна, Пугачевська Катерина Йожефівна. Детермінанти експортооріснтованості відкритих економік.

Метою статті є дослідження детермінант експортної орієнтованості в умовах неопротекиіонізму ХХІ століття та ідентифікація рівня експортної орієнтованості економіки України на основі комбінаторного підходу, який трунтується на розрахунку показників відкритості та товарної структури експорту. У статті досліджуються ключові тенденції лібералізації зовнішньої 
торгівлі. Проаналізовано погляди провідних економічних шкіл у частині взаємозв'язку між зовнішньоторговельною політикою та економічним зростанням. Отримані результати засвідчили тендениію розширення практики застосування регуляторних заходів як з боку урядів краӥн, так і міжнародних інституиій; координування і сприяння міжнародній співпращі у сфері лібералізаџії зовнішньої торгівлі; зростання практики використання нетарифних заходів з метою захисту вітчизняного ринку від іноземної конкурениії. Емпіричне підгрунтя отриманих результатів дозволило сформулювати пріоритети розиирення експорту України з урахуванням детермінант експортоорієнтованості у сучасних умовах.

Ключові слова: експортна орієнтованості, просування експорту, відкрита економіка, політика фритредерства, міжнародна конкурентоспроможність.

Introduction. In the context of globalization, the dependence of the economies of the vast majority of countries on the structural changes of the world economy as a whole, and international trade in particular, is increasing. Countries participating in international trade use the tools and principles of liberalism and protectionism in foreign trade, depending on the vectors of international economic policy. Research of the practice of using trade barriers shows the gradual transition of national trade regimes from rigid protectionism to the growing openness of national economies. At the same time, the tendencies that have taken place in recent years in the sphere of foreign trade relations have led to the emergence of regional trade agreements, which are the response of individual countries to the need to support exporting enterprises. Over the last decade, the number of such agreements has grown substantially, and is now expanding to over $50 \%$ of international trade, along with multilateral agreements within the WTO. A key feature of such agreements is the mutual preferential trade agreements between two or more partners. Such preferences may apply to antidumping policies, countervailing duties, sanitary barriers, i.e. those areas that are subject to WTO rules, but individual agreements regulate competition policy, capital and investment migration, anti-corruption policy, environmental legislation.

The lack of a unified policy on state export promotion, even in terms of WTO membership, has led to the separation of regional trade agreements into a separate group of instruments to increase the intensity and scale of state support for exports in order to increase the competitiveness of exporting enterprises and, as a result, the national economy.

In the context of globalization, export support is one of the directions of modern economic policy of foreign countries. In order to increase national competitiveness, developed and developing countries have significantly stepped up the intensity and scale of state support for exports. For Ukraine, this issue is particularly relevant given its high level of foreign trade openness and in the context of the implementation of the Association Agreement with the EU. Taking into account the abovementioned, 
Ukraine must keep pace with global trade trends and adapt to changes that are taking place.

Analysis of recent researches and publications. The need to research the issue of export support is justified by scientists, who point to the need to synthesize different studies to obtain reliable results on the interdependence of export-oriented development, export dependence and export-promotion of national producers (Korablin, 2017; Sidenko, 2017; Shynkaruk, 2011; Skrypnychenko, 2015). The growing interest in export activities is driven by the transformation of the world economy, as well as the multifaceted manifestations of internationalization, which are reflected in the diffusion of new technologies, the conclusion of new trade agreements between countries, the reduction of trade barriers etc.

Currently thought-provoking issue is how to keep commitments on mutual market access as WTO members in terms of neo-protectionism of the 21 st century. In this context, scientific findings are interesting, in which the policy of modern competition is revealed through particularities in different groups of countries (Leonidou et al., 2012, Bernini et al., 2016). However, the conclusion that regulatory support is most likely to be subject to determinants on the basis of specificity of national and regional models of economic development that rely on cultural foundations are, in the authors' view, important but insufficient as they lack the economic framework to formulate such generalizations. Thus, the aim of the article is identifying determinants of export orientation in modern conditions.

Presenting main material. The accelerated development of foreign trade operations in comparison with the dynamics of economic processes is one of the key features of the era of economic globalization. The statistics provided by the United Nations Conference on Trade and Development (Table 1) clearly show the long-term trend of export growth over of GDP growth. Starting from 1992, the coefficients of export growth rate over GDP is averaging from 1.08 to 4.36 (except for 2011-2016, which indicates a decrease in the importance of exports during this period as the main engine of global economic growth, mainly due to a decrease in the intensity of investment processes). These coefficients are particularly high in 2017-2018 for transition economies (11.48 and 8.23, respectively) and economically developed countries (3.91 and 3.87).

Table 1

\section{Growth rates of exports of goods and GDP by groups of countries with different} levels of economic development, \%

\begin{tabular}{|c|c|c|c|c|c|c|c|}
\hline Group of counties & $\begin{array}{c}1992- \\
1995\end{array}$ & $\begin{array}{c}1995- \\
2000\end{array}$ & $\begin{array}{c}2000- \\
2005\end{array}$ & $\begin{array}{c}2005- \\
2010\end{array}$ & $\begin{array}{c}2011- \\
2016\end{array}$ & 2017 & 2018 \\
\hline \multicolumn{7}{|c|}{ Growth rates of exports of goods, $\%$} & \\
\hline World & 11.30 & 3.65 & 11.42 & 6.27 & 1.16 & 10.61 & 9.83 \\
\hline Developing economies & 14.01 & 5.76 & 14.37 & 9.21 & 1.89 & 11.78 & 10.41 \\
\hline Transition economies & 22.30 & 1.83 & 19.97 & 9.44 & -3.18 & 24.10 & 23.12 \\
\hline Developed economies & 10.02 & 2.79 & 9.54 & 4.10 & 0.92 & 8.95 & 8.56 \\
\hline
\end{tabular}




\begin{tabular}{|c|c|c|c|c|c|c|c|}
\hline Group of counties & $\begin{array}{c}1992- \\
1995\end{array}$ & $\begin{array}{c}1995- \\
2000\end{array}$ & $\begin{array}{c}2000- \\
2005\end{array}$ & $\begin{array}{c}2005- \\
2010\end{array}$ & $\begin{array}{c}2011- \\
2016\end{array}$ & 2017 & 2018 \\
\hline \multicolumn{7}{|c|}{ Growth rates of GDP, $\%$} & \\
\hline World & 2.59 & 3.37 & 2.93 & 1.91 & 2.41 & 3.07 & 3.60 \\
\hline Developing economies & 5.23 & 4.27 & 5.44 & 5.88 & 4.29 & 4.39 & 4.52 \\
\hline Transition economies & -9.87 & 1.51 & 6.60 & 3.61 & 0.54 & 2.10 & 2.81 \\
\hline Developed economies & 2.37 & 3.18 & 2.11 & 0.46 & 1.62 & 2.29 & 2.21 \\
\hline \multicolumn{8}{|c|}{ Coefficient of growth in exports of goods over GDP } \\
\hline World & 4.36 & 1.08 & 3.90 & 3.28 & 0.48 & 3.46 & 2.73 \\
\hline Developing economies & 2.68 & 1.35 & 2.64 & 1.57 & 0.44 & 2.68 & 2.30 \\
\hline Transition economies & -2.26 & 1.21 & 3.03 & 2.62 & -5.91 & 11.48 & 8.23 \\
\hline Developed economies & 4.22 & 0.88 & 4.53 & 8.93 & 0.57 & 3.91 & 3.87 \\
\hline
\end{tabular}

Source: conducted by the authors on the basis of United Nations Conference on Trade and Development.

The structure of world exports for more than 50 years has also undergone significant transformations. Thus, the share of economically developed countries decreased from $70.84 \%$ in 1960 to $51.92 \%$ in 2018 , while the share of developing countries increased from $24.41 \%$ to $44.60 \%$ (Table 2). Among them, China had a significant growth rate of exports, which accounted for $1.97 \%$ in world exports in 1960 , but as a result of the implementation of reform and openness policies it began to grow in $2000-3.41 \%$, in $2011-10,35 \%$, and in $2018-12,77 \%$. The second and third place in the share of world exports in 2018 is the USA and Germany with figures of $8.54 \%$ and $8.01 \%$ respectively.

Table 2

\section{Structure of world exports of goods in 1960-2018 by groups of countries with different levels of economic development, \%}

\begin{tabular}{|l|c|c|c|c|c|c|c|c|c|}
\hline \multicolumn{1}{|c|}{$\begin{array}{c}\text { Group of } \\
\text { counties }\end{array}$} & 1960 & 1970 & 1980 & 1990 & 2000 & 2010 & 2015 & 2016 & 2018 \\
\hline $\begin{array}{l}\text { Developed } \\
\text { economies }\end{array}$ & 70,84 & 76,40 & 66,34 & 72,41 & 65,77 & 53,94 & 52,23 & 53,56 & 51,92 \\
\hline $\begin{array}{l}\text { Developing } \\
\text { economies }\end{array}$ & 24,41 & 19,03 & 29,46 & 24,17 & 31,85 & 41,99 & 44,59 & 43,65 & 44,60 \\
\hline $\begin{array}{l}\text { Transition } \\
\text { economies }\end{array}$ & 4,76 & 4,57 & 4,20 & 3,41 & 2,39 & 4,06 & 3,18 & 2,79 & 3,48 \\
\hline
\end{tabular}

Source: conducted by the authors on the basis of United Nations Conference on Trade and Development.

For countries that have made the transition to a market economy in the last decades, both unprecedented opportunities and significant risks are opening up in the global context of structural changes in the economy. The potential for successful economic policies to dominate the world market (as demonstrated by China, the Republic of Korea, and other countries in East Asia) depends on a purposeful public 
policy for the development and proactive pursuit of innovation. Instead, the risks are related, first of all, to the lack of response of the society, government and business elites to the new demands of the times (Shynkaruk \& Sidenko, 2011).

Increasing the degree of export orientation has a positive impact on the undeveloped economies through the initiation of a comparative advantage mechanism, which allows the country to concentrate its production capabilities on those segments for which it has relatively better conditions. However, the fact that active participation in international trade has significant advantages over the autarchy model does not mean that the infinite expansion of the country's exports is effective (Shynkaruk \& Sidenko, 2011).

J. Bhagwati identified the conditions according to which «impoverished growth» in international trade could occur, in particular: worsening trade conditions, low elasticity of demand for goods - key export positions of the country, low elasticity of demand for imported goods at price, reduction goods as a result of increased imports, a high proportion of imports in consumption (Bhagwati, 1957). Hypertrophy of the export-oriented sector of the economy is characteristic of countries with underdeveloped internal market in the context of neoliberal globalization, under which the mechanisms of industrial policy in less developed countries are dismantled under the pressure of global organizations and governments of leading countries. As a consequence, the process of import substitution of unprofitable economic activities from a global point of view is increasing. However, given that such activities are often an important prerequisite for the development and satisfaction of basic needs of the population, such an evolution of the structure leads to an increase in the share of priceinelastic critical imports, which increases the likelihood of «Bhagwati conditions». The impoverished growth mechanism is not the only threat to countries with hypertrophied export sector. Potential risks for countries include the Dutch disease mechanism, which occurred during the transition period in some post-Soviet countries. Its essence is the de-industrialization of the economy as a result of the discovery of a new source of natural resources. The main feature of the "Dutch disease» is the increase in the national currency of the country as a result of improving the trade balance, which reduces the competitiveness of manufacturing industries. In Ukraine, it has taken on a slightly modified form and was associated not with the raw materials sector but with semi-finished products. Its essence was to replace more complex production with simpler use of less skilled labor - with a corresponding depreciation of accumulated human capital (Shynkaruk \& Sidenko, 2011; Bernini et al., 2016).

According to international comparisons, the Ukrainian economy is quite open, as its exports of goods and services to GDP fluctuate within 50\%. Data from the United Nations Conference on Trade and Development indicate that in 2016-2017 it was $49.3 \%$ and $48.0 \%$, respectively, and significantly exceeded the world average of $28.3 \%$ in 2017 (Table 3). Ukraine's openness to import operations is also significantly higher than the world average. In 2016-2017 it was 56.2\% and 55.9\% respectively. 


\section{Comparative analysis of the dynamics of openness indicators of Ukraine and the world in $2005-2017, \%$}

\begin{tabular}{|l|l|l|l|l|l|l|l|l|l|l|l|l|}
\hline & 2005 & 2007 & 2008 & 2009 & 2010 & 2011 & 2012 & 2013 & 2014 & 2015 & 2016 & 2017 \\
\hline \multicolumn{10}{|c|}{ Export quota } \\
\hline World & 27,0 & 29,7 & 31,0 & 26,2 & 28,5 & 30,4 & 30,3 & 30,4 & 30,1 & 28,3 & 27,3 & 28,3 \\
\hline Ukraine & 47,8 & 41,3 & 43,8 & 42,8 & 48,2 & 51,3 & 49,2 & 44,6 & 49,0 & 52,6 & 49,3 & 48,0 \\
\hline \multicolumn{10}{|c|}{ Import quota } \\
\hline World & 26,6 & 28,9 & 30,4 & 25,5 & 27,8 & 29,7 & 29,5 & 29,4 & 29,4 & 27,7 & 26,7 & 27,6 \\
\hline Ukraine & 47,0 & 46,8 & 51,5 & 44,5 & 51,2 & 57,5 & 57,4 & 53,1 & 52,5 & 55,2 & 56,2 & 55,9 \\
\hline
\end{tabular}

Source: conducted by the authors on the basis of United Nations Conference on Trade and Development.

There are countries with a much higher export quota in the world. In particular, in Hong Kong in 2017 it was $188.3 \%$ (in 2013 - 221.6\%), in Singapore - 173.4\% (in $2008-231.4 \%$ ). However, such colossal values are reflection not only of the extraordinary economic development but also of the offshore status of the country with its high level of re-export activity (Korablin, 2017).

The abovementioned trade openness of the domestic economy is further enhanced by the fact that almost $60 \%$ of export operations of large taxpayers occur under indirect contracts.

In Ukraine, the production of raw materials with a low level of value added dominates over a long period. Unfortunately, many Ukrainian enterprises, including Motor Sich, Antonov, Pivdenmash, and Hartron, are more likely to be production symbols of national capabilities than the technological basis of the domestic economy (Korablin, 2017).

According to the World Bank, the average share of high-tech products in the structure of industrial exports of Ukraine in 2017 was 5.0\%, which is 3 times less than the world average (16.1\%) (Table 4).

Such technological segmentation is evident in view of the commodity structure of exports, which is dominated by primary manufactured products, including ferrous metals, cereals, vegetable oils, ores, slag and ash, and chemical fertilizers.

\section{Table 4}

\section{Indicators of high-tech products (HTP) export of individual countries in 2017}

\begin{tabular}{|c|l|c|c|c|c|c|c|}
\hline № & Country & $\begin{array}{c}\text { Export of } \\
\text { HTP, mln } \\
\text { USD }\end{array}$ & $\begin{array}{c}\text { Share of HTP } \\
\text { in industrial } \\
\text { exports, } \%\end{array}$ & № & Country & $\begin{array}{c}\text { Export of } \\
\text { HTP, mln } \\
\text { USD }\end{array}$ & $\begin{array}{c}\text { Share of HTP } \\
\text { in industrial } \\
\text { exports, \% }\end{array}$ \\
\hline 1 & Singapore & 136,16 & 49,2 & 18 & Israel & 7,36 & 13 \\
\hline 2 & Hong Kong & 141,72 & 29,7 & 19 & Canada & 24,22 & 12,9 \\
\hline
\end{tabular}




\begin{tabular}{|c|c|c|c|c|c|c|c|}
\hline № & Country & $\begin{array}{l}\text { Export of } \\
\text { HTP, mln } \\
\text { USD }\end{array}$ & $\begin{array}{c}\text { Share of HTP } \\
\text { in industrial } \\
\text { exports, } \%\end{array}$ & № & Country & $\begin{array}{c}\text { Export of } \\
\text { HTP, mln } \\
\text { USD }\end{array}$ & $\begin{array}{c}\text { Share of HTP } \\
\text { in industrial } \\
\text { exports, } \%\end{array}$ \\
\hline 3 & Malaysia & 41,17 & 28,1 & 20 & Poland & 13,68 & 7,7 \\
\hline 4 & China & 504,38 & 23,8 & 21 & Bulgaria & 1,34 & 7,6 \\
\hline 5 & France & 98,69 & 23,5 & 22 & Croatia & 782,00 & 7,5 \\
\hline 6 & Kazakhstan & 1,77 & 22,7 & 23 & India & 14,46 & 7 \\
\hline 7 & Ireland & 25,73 & 21,4 & 24 & Spain & 15,57 & 7 \\
\hline 8 & United Kingdom & 68,63 & 21,1 & 25 & Italy & 27,79 & 6,8 \\
\hline 9 & Netherlands & 63,62 & 18,6 & 26 & Chile & 590,00 & 6,1 \\
\hline 10 & Norway & 3,59 & 18,4 & 27 & Tunisia & 603,00 & 5,2 \\
\hline 11 & Latvia & 1,34 & 16,6 & 28 & Guatemala & 234,00 & 5,1 \\
\hline 12 & $\begin{array}{l}\text { Republic of } \\
\text { Korea }\end{array}$ & 72,70 & 14,2 & 29 & Moldova & 29,00 & 5,1 \\
\hline 13 & Germany & 171,63 & 13,9 & 30 & Portugal & 2,35 & 5 \\
\hline 14 & Hungary & 13,48 & 13,8 & 31 & Ukraine & 1,01 & 5 \\
\hline 15 & Japan & 83,66 & 13,8 & 32 & Cameroon & 29,00 & 4,7 \\
\hline 16 & USA & 110,12 & 13,8 & 33 & Peru & 197,00 & 4,7 \\
\hline 17 & Sweden & 15,01 & 13,2 & 34 & Yemen & 3,00 & 4,7 \\
\hline
\end{tabular}

Source: conducted by the authors on the basis of World Bank.

An analysis of the structure of Ukraine's exports by broad economic categories revealed a predominance in exports of intermediate goods $(82.88 \%$ in 2017) and a small share of means of production (3.27\% in 2017) (Table 5).

The long-term evolution of the structure of Ukrainian exports moves in parallel to structural shifts in the economy as a whole. At the same time, changes in the structure of Ukraine's exports, in the absence of effective national policy in realizing the structural priorities of economic development, played a powerful catalyst for the processes of structural simplification of the Ukrainian economy (Sidenko, 2018; Skrypnychenko et al., 2015).

Table 5

Export structure of Ukraine by Broad Economic Categories in 2005-2017

\begin{tabular}{|c|l|c|c|}
\hline BEC & \multicolumn{1}{|c|}{ Commodity group } & 2005 & 2017 \\
\hline \multicolumn{2}{|c|}{ Consumer goods } & 11,08 & 12,89 \\
\hline 112 & Food and beverages, primary, mainly for household consumption & 1,13 & 1,45 \\
\hline 122 & Food and beverages, processed, mainly for household consumption & 4,33 & 5,46 \\
\hline 61 & Consumption goods nes, durable & 1,14 & 1,52 \\
\hline 62 & Consumption goods nes, semi-durable & 2,14 & 2,31 \\
\hline 63 & Consumption goods nes, non-durable & 2,35 & 2,14 \\
\hline \multicolumn{2}{|c|}{ Goods for intermediate consumption } & 84,47 & 82,88 \\
\hline 111 & Food and beverages, primary, mainly for industry & 11,81 & 11,90 \\
\hline 121 & Food and beverages, processed, mainly for industry & 9,28 & 9,36 \\
\hline 21 & Industrial supplies nes, primary & 16,57 & 15,54 \\
\hline 22 & Industrial supplies nes, processed & 37,87 & 37,23 \\
\hline 42 & Parts and accessories of capital goods (except transport equipment) & 2,61 & 2,79 \\
\hline 31 & Fuels and lubricants, primary & 0,31 & 0,11 \\
\hline
\end{tabular}




\begin{tabular}{|c|l|c|c|}
\hline BEC & Commodity group & 2005 & 2017 \\
\hline 32 & Fuels and lubricants, processed & 0,90 & 1,44 \\
\hline 53 & Parts and accessories of transport equipment & 5,12 & 4,52 \\
\hline \multicolumn{2}{|c|}{ Capital goods } & 4,04 & 3,27 \\
\hline 41 & Capital goods (except transport equipment) & 3,06 & 2,69 \\
\hline 521 & Transport equipment, other, industrial & 0,98 & 0,58 \\
\hline \multicolumn{2}{|c|}{ Other categories } & 0,41 & 0,96 \\
\hline
\end{tabular}

Source: conducted by the authors on the basis of United Nations Comtrade Database.

For Ukraine, the urgent task of reorienting development priorities, which, in addition to existing ones, should include moving away from one-sided export orientation while strengthening domestic demand, in particular in high-tech industries and diversifying the export structure itself in the direction of increasing the share of high-tech goods and services.

Conclusion. Contrary to the tendency of increasing openness of national economies, free trade policy has its peculiarities in different groups of countries and is differentiated according the specificity of national and regional models of economic development, which in turn reflect the priorities determined by objective factors (in particular, natural resources, size and geographical location of the country, etc.), as well as subjectively established orientations based on the cultural and value foundation.

The study of empirical and statistical information has made it possible to identify that increasing the level of export orientation has a positive impact on undeveloped economies through the initiation of a comparative advantage mechanism, which allows the country to concentrate its production capabilities on those segments for which it has relatively better conditions, but actively participating in international trade does not mean that the infinite expansion of the country's exports is effective in view of the «impoverished growth», which in terms of neoliberal globalization acquire a special reality due to the specific realities of pricing on the one hand, and the formation of economic structures - on the other.

\section{REFERENCES}

1. Bernini M., Du J. \& Love J. (2016) Explaining intermittent exporting: Exit and conditional re-entry in export markets. Journal of International Business Studies, Vol. 47, 1058-1076 doi:10.1057/s41267-016-0015-2 [in English]

2. Bhagwati J. (1958) International trade and economic expansion. American Economic Review, Vol. 48. No.5. P.941-953 [in English]

3. Korablin S. (2017) Makroekonomichna dynamika Ukrainy: pastka syrovynnykh rynkiv [Macroeconomic dynamics of Ukraine: the trap of commodity 
markets]. Kyiv : Institute of Economics and Forecasting of the NAS of Ukraine [in Ukrainian]

4. Leonidou L., Palihawadana D. \&Theodosiou M. (2011) National ExportPromotion Programs as Drivers of Organizational Resources and Capabilities: Effects on Strategy, Competitive Advantage, and Performance. Journal of International Marketing, Vol 19, Issue 2. https://doi.org/10.1509/jimk.19.2.1 [in English]

5. Shynkaruk L., Sidenko V. (2011) Strukturni zmini ta ekonomichnij rozvitok Ukrayini [Structural changes and economic development of Ukraine]. Kyiv : Institute of Economics and Forecasting of the NAS of Ukraine [in Ukrainian]

6. Sidenko V. (2017) Strukturni transformatsii u svitovii ekonomitsi: vyklyky dlia Ukrainy [Structural transformations in the global economy: challenges for Ukraine]. Kyiv : Zapovit [in Ukrainian]

7. Sidenko V. (2018) Hlobalni strukturni transformatsii ta trendy ekonomiky Ukrainy [Global structural transformations and trends of Ukrainian economy]. Retrieved from http://razumkov.org.ua/uploads/article/EP_18_1_37_uk.pdf [in Ukrainian]

8. Skrypnychenko M. et al. (2015) Modeli identyfikatsii makroekonomichnykh dysbalansiv $\mathrm{v}$ Ukraini [Models for identification of macroeconomic imbalances in Ukraine]. Kyiv : Institute of Economics and Forecasting of the NAS of Ukraine [in Ukrainian]

9. UNCTAD Statistics. Retrieved from http:/unctadstat.unctad.org/EN/ [in English]

10. UN Comtrade Database. Retrieved from https://comtrade.un.org/data [in English]

11. World Development Indicators. Retrieved from: http://wdi.worldbank.org/ table/5.13\# [in English]

12. $60 \%$ eksportnykh operatsii prokhodiat cherez ofshory $[60 \%$ of export operations go through offshore]. Retrieved from https://www.epravda.com.ua/ news/2017/10/19/630267/ [in Ukrainian] 